\title{
TEACHING HORTATORY EXPOSITION TEXT THROUGH CLUSTERING TECHNIQUE
}

\author{
Samsul Amri \\ S1 - English Education Department \\ Universitas Islam Indragiri - Tembilahan Riau \\ mr.amri85@gmail.com
}

\begin{abstract}
Having writing problems was faced by students. This research purposed to describe the teaching process how Clustering Technique improves the students' writing skill of hortatory exposition text, and what influenced factors of their writing improvement. This is a Classroom Action Research. The participants of the research were the students of grade XI AB-3 of MA Darul Hikmah Pekanbaru. The data were collected in each cycle from observation checklists, field notes, interviews, and writing tests. Then the researcher found that Clustering Technique enables to improve better the students' writing skill of hortatory exposition text through the process of socializing, reviewing, controlling, monitoring, assisting, motivating, and practicing. Consequently, the students could improve their writing skill which involved the mean score improvement of writing indicators; grammar, vocabulary, mechanics, fluency, and organization. It could be seen from the improvement of the base score mean score (56.32), post-test I (64.23), and posttest II (73.85). Furthermore, the factors that influenced the improvement of their writing skill involved creative thinking, students' motivation, amount of writing practices, students' prior knowledge, and the teacher's role. To sum up, the implementation of Clustering Technique in teaching writing of hortatory exposition text could provide positive results on their writing skill.
\end{abstract}

Keywords: Clustering Technique, Hortatory Exposition, writing Skill, cycle, improvement.

\section{INTRODUCTION}

Writing is an essential language skill. One is able to express his ideas and thoughts by writing. Through writing, he can restate information that he understands from texts or articles as well as information that he listens to. Moreover, it is also a very useful language skill to deliver information through written communication.

Accordance with curriculum school as well as referring to the Basic Competence of writing skill for the second year of Senior High Schools students, it is expected that the students enable to express meaning and rhetorical steps of simple essay in daily life and knowledge usage accurately, fluently and understandably in the form of narrative, spoof, and hortatory exposition. In brief, 
teaching writing for the students is intended to encourage them how to be able to express both meaning and rhetorical in the form of some texts.

One genre that is taught to the students of Senior High School is hortatory exposition text. It is a kind of text, which is to persuade the reader or listener that something should or should not be accepted by providing logical arguments (Hartono, 2005:6-9). It comprises three main organizations; thesis, arguments, and recommendation. Its characteristics can be seen through its language features, which focus on generic human and non-human participants. It also uses mental process, material processes, and relational processes.

Writing, one of the productive language skills, might be a problem for some language learners in learning English since there are several aspects that should be gained. Some previous theories and research findings have found that Heaton (1991: 135) says that writing skill is a complex skill and sometimes difficult to be learned, the learners should require not only mastery grammar but also sharing the information and writing elements. Mumtaz (2007:15) says that in writing the learners should have the ability to tell information (generating ideas). Then, Richard and Renandya (2010:303) explain that writing is the most difficult skill for learners to master. The difficulty is not only in generating and organizing ideas but also in translating the ideas into readable text. In short, writing seems hard to be implemented because of some considerations.

The theories and previous research results also occur at MA Darul Hikmah Pekanbaru. During the teaching-learning process, the researcher found that the students got difficulty in writing. When he asked for them to write a hortatory exposition text, he observed that none of them used a pre-writing technique. After scoring a test, it was found that they were a lack in their components of writing which covers language use, vocabulary, mechanics, fluency, and organization. Then, the total of average score of their writing performance was categorized as poor writing skill, and also it did not achieve the passing grade for English subject at MA Darul Hikmah Pekanbaru.

The students' problems in grammar and mechanics terms could be seen from their mean scores which were classified as low ability. They had difficulties in using correct grammar. For example, one of the students wrote a sentence "many kinds of cell phones there are: nokia, nexian, $B B$, samsung and etc." The sentence was written in incorrect grammar and punctuation (capital letters). It indicated that the students had problems with their grammar and mechanics mastery. Some students have difficulty in generating their ideas in writing. It could be seen from the contents of their composition, which was lack of the ideas. It might happen since they obtained obstacles to generate their ideas in their writings. Moreover, it could occur because before writing they did not use a prewriting technique to generate their ideas. Furthermore, the students lost controlling their writing organization. Some students could not enable to write the text based on the schematic of hortatory exposition text which consists of thesis, arguments, and recommendations. In addition, the students also had the problem in vocabulary mastery. They often asked the teacher for unknown vocabularies even simple or easy vocabularies.

Those problems could occur because of two factors; internal and external factors. The internal factor could be from students' motivation and interest. While the students had a great motivation and interest in writing, they would enable to 
achieve the goal of writing skill easily. Whereas, the external factor involves teaching facilities and teacher's teaching technique or strategy. There are several writing techniques and strategies that can be applied such as Listing, Brainstorming, Clustering, Graphic Organizer, Collaborative Writing Strategy (CWS), Small Group Discussion, Using Pictures, and others. When the teacher has an appropriate writing teaching technique, it causes the students more motivated and interested in writing. Consequently, it is easier for them to achieve an ideal goal of writing.

Therefore, based on the students' problems and the empirical data, the researcher focused on solving the students' problems in teaching technique aspect. In this study, he implemented the Clustering Technique in teaching writing skill of hortatory exposition text. Lindbergh (2008) says Clustering is a type of prewriting that helps people who were visually oriented. It has been widely used for academic writing (university level) to help students in generating ideas before composing a text. Yet, it has not been recognized for senior high school students. Through Clustering Technique, language learners can use visual markers, rectangles, arrows, and circles to develop their ideas before starting writing. The words are circled and then linked by lines to show discernible clusters. The form of clustering technique is easy to understand especially for the students and it may bring a new style of writing activity.

To support the researcher's point of view, some previous research results (Marliasari, 2008; Al-Jarf, 2009; Styati, 2010) have proven that the implementation of Clustering Technique on the students' writing performance provides positive contributions. Through this inquiry, an improvement of the students' writing skill was expected after implementing the technique. They, as the results, would be able to compose hortatory exposition text easier by considering the indicators, and the process of writing.

The intervention, Clustering Technique, is designed to improve the language and writing skill of high school EFL students. The purpose of this study was to describe the process and influence factors of the students' writing improvement. Thus, it could be formulated two research questions:

1. How does Clustering Technique improve the students' writing skill of hortatory exposition text?

2. What are the influencing factors of the students' writing skill improvement?

\section{LITERATURE REVIEW}

\section{Writing Skill}

There are many experts who have given the point of view related to the nature of writing. Harmer (1991:16) states that writing is one of the four basic language skills, which is categorized as productive skill. It is essential to master English as well as a subject that must be taught at senior high schools. In addition, it is one of the skills, which is able to enhance students' language and stimulate their cognitive ability in learning a language.

Additionally, Brown (2001:335), Myles (2002:1), and Mumtaz (2007:15) say that writing is not easy to be conducted since students need to consider several processes of writing in order to be able to generate a good composition. The 


\section{Samsul Amri \\ HORTATORY EXPOSITION TEXT \\ THROUGH CLUSTERING TECHNIQUE}

process covers result of the complex process (thinking, drafting, and revising procedures) that require specialized skill, which is not every speaker develops naturally, it is usually learned or transmitted as a set of practices in formal instructional settings and process (through experience).

The importance of writing as a language skill, writing skill is necessary to be taught for senior high school students. According to Yan (2006:3), and Kellogg and Raulerson (2007:1) as a productive skill, it places a great demand on students logical and critical thinking. In writing there is a process which covers starting, progressing and finishing. It needs to activate a lot of different skills and orientations. Therefore, to achieve a good writer, a writer needs to activate other skills as reading and listening. A good writing is a major cognitive ability because it could be a test of memory, language, and thinking ability.

Moreover, Partel and Jain (2008:125), Li (2000:1) view that writing skill is essential features of learning a language because it provides a very good means of exploring vocabulary, spelling, and sentence patterns as well as provides an excellent consolidating activity. It is able to be a crucial factor for the students at the higher stage [academic areas] and to become independents and productive citizen.

In doing a good composition, a writer should consider several components of writing. O'Malley and Pierce (1995:142), and Hughes (2003: 101-102) explain some indicators of writing, which cover content (idea development), organization, vocabulary (word choice), language use [rules of form], mechanics, fluency [style and easy of communication], unity, and coherence. It is expected that a writer is able to use all the indicators in their writing in order to generate a good composition.

\section{Hortatory Exposition Text}

Recently, the word "genre or text" has been well-known for English teachers, and students at junior and senior high schools. According to Chandler (2000:1), the word "genre" comes from the French (and originally Latin), which means kind or class. The term refers to a distinctive type of text. In the same concept, Hartono (2005:4) defines that the term "genre" is used as referring to particular text-types, not to traditional varieties literature. It is a type of text, which has a particular social purpose and level context.

One of the texts is hortatory exposition text. According to Derewianka (1992:71), Hartono (2005:6), the main goal of hortatory exposition text is to persuade the reader or listener related to the case given by showing the information logically. it is categorized as argumentative text since it comprises several arguments. As other texts, it has its own schematic organization. It has a well-organized structure, which covers three main points; (1) thesis, it is the first part of hortatory exposition text, which is commonly written at the beginning of the paragraph. Moreover, it attempts to build up an introduction of the issue concerned in an opening statement. (2) Argumentations, it is the second stage of hortatory text; its main purpose is to provide a series of arguments to convince and lead the readers to believe the writer's viewpoint. And (3) recommendation, it strengthens the writer's point of view by stirring up the readers' feeling and directs them to follow or agree to the waiter's recommendations. To simplify, hortatory exposition text is a sort of genre which has the main objective to ask the readers or 
listeners to receive the notion that given by an author through presenting rational arguments. Then, its generic structure covers thesis, argumentation, and recommendation.

The example of hortatory exposition text could be seen in the following:

\title{
Thesis
}

\section{Should Ads be banned from TV Program?}

I am writing to complain about ads on TV. There were so many ads, especially during my favorite programs. I think they should be stopped for a number of reasons.

\begin{abstract}
Arguments
First, ads were a nuisance. They go on for a long time and there were so many. Sometimes there seem to be more ads than programs. Second, ads were a bad influence on people. They try to encourage people to buy unhealthy food like beers, soft drinks, candies, and chips. In other words, they make want things they do not really need and cannot afford. Finally, ads play role in what programs people watch. That is because there were lots of ads in popular programs that a lot of people watch. Some programs which were not so popular get stopped because they do not attract enough ads, even though those programs may be someone's favorite.
\end{abstract}

\section{Recommendation}

For those reasons, I think TV stations should stop showing ads. They interrupt programs. They were a bad influence on people and they sometimes put a stop to people's favorite shows. I am sick of ads and now I mostly watch a movie in a cinema.

(Taken from: Look Ahead book Class 2 SMA)

\section{Clustering Technique}

A pre-writing technique is crucial in doing writing. According to Osterholm in Homstad and Thorston (1994:31), several strategies are listed for facilitating the process of writing. They include invention pre-writing strategies such as brainstorming, clustering, free-writing, and mapping.

One of the pre-writing techniques is Clustering. According to Oshima and Hogue (1999:8) define that Clustering is another brainstorming activity which could be used to produce ideas in writing. It aims to be easier to explore ideas by blocking them on a sheet of paper. People who use clustering often develop unique visual markers, using rectangles, arrows, and circles to diagram their ideas. Moreover, Dawson and Essid (2010) define that clustering technique is a kind of pre-writing technique that allows a writer to explore a lot of ideas that he needs. Students will need to practice the clustering model several times before they will think to use it independently.

Additionally, Oshima and Hogue (1999:8) explain the procedures for implementing the Clustering Technique to help students in developing their writing ideas. Firstly, the teacher or students draw a central cluster in the center of the paper, write a topic and draw clusters around it. Then, the teacher or students 
write whatever ideas come in balloons around the center. It is to support the ideas in the center cluster. Moreover, the teacher or students think about each of these ideas and make more clusters around them. Finally, the teacher or students start to write writing based on the ideas that have written in the clusters.

The example of the Clustering Technique diagram could be seen as follows, which is adapted from Oshima and Hogue (1999:8) and Grace and Sudarwati (2007:198).

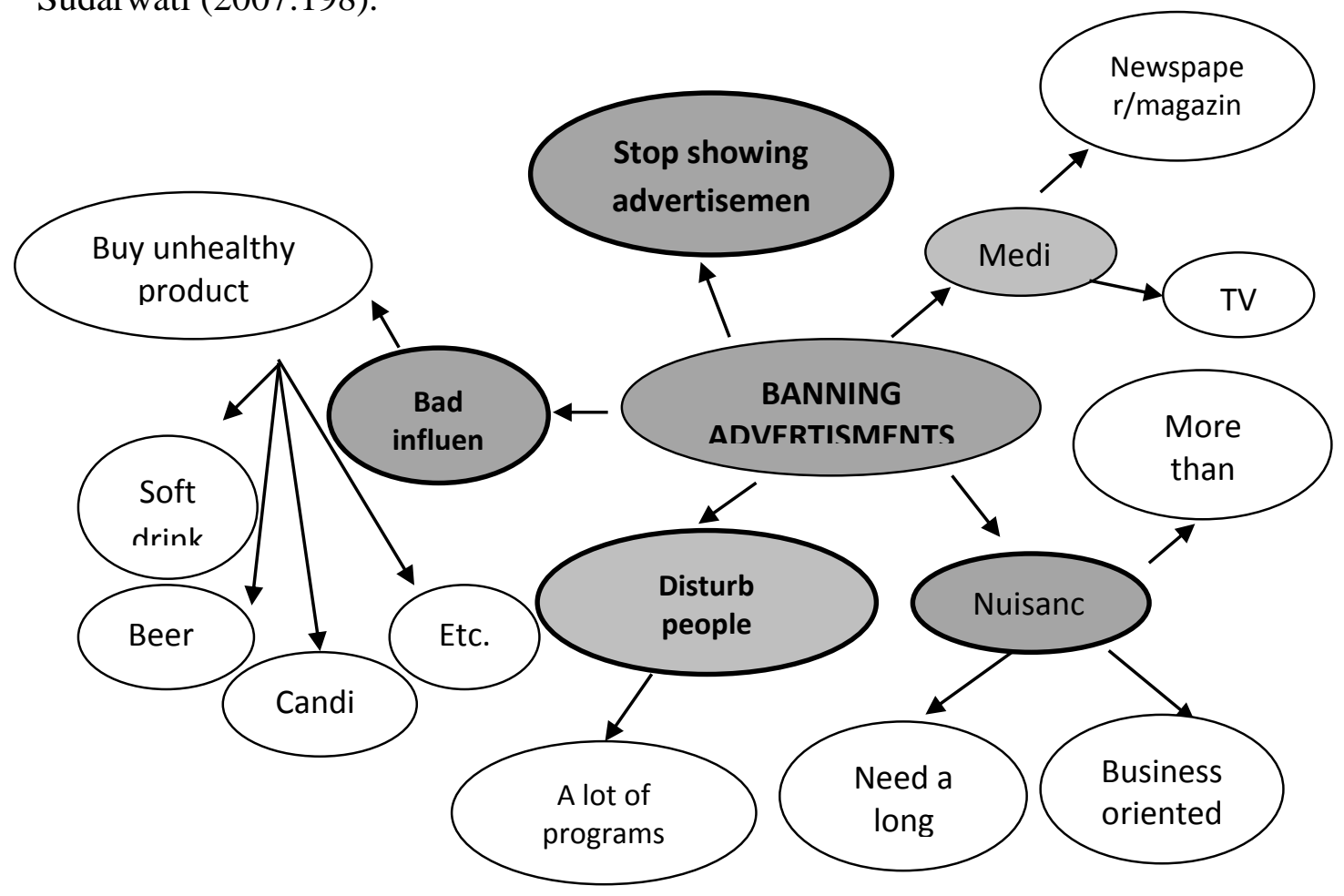

\section{RESEARCH METHOD}

This is a classroom action research. According to Creswell (2005:550), Anna, et.al (2006:1), action research is a form of self-reflective investigation of participants (the teacher and the students) in social and educational situations as well in order to improve their own social or educational practices. It commonly arises because of a problem in the learning activity. In addition, classroom action research is carried out through a well-organized (cycles) process, which involves plan, action, observation, and reflection. It is expected that a teacher can implement certain treatments in order to provide an improvement to the students.

The subject of this study was the XI AB-3 students of MA Darul Hikmah Pekanbaru. There were 26 students; 20 females and 6 males. The research was carried out during less and more three months. During ten meetings the researcher applied Clustering Technique as a technique in writing. In collecting the data, the researcher used writing tests, observation sheets (observation checklist for teacher and students activities, and field notes) and interview. Then, the data were analyzed through qualitative and quantitative analysis. 


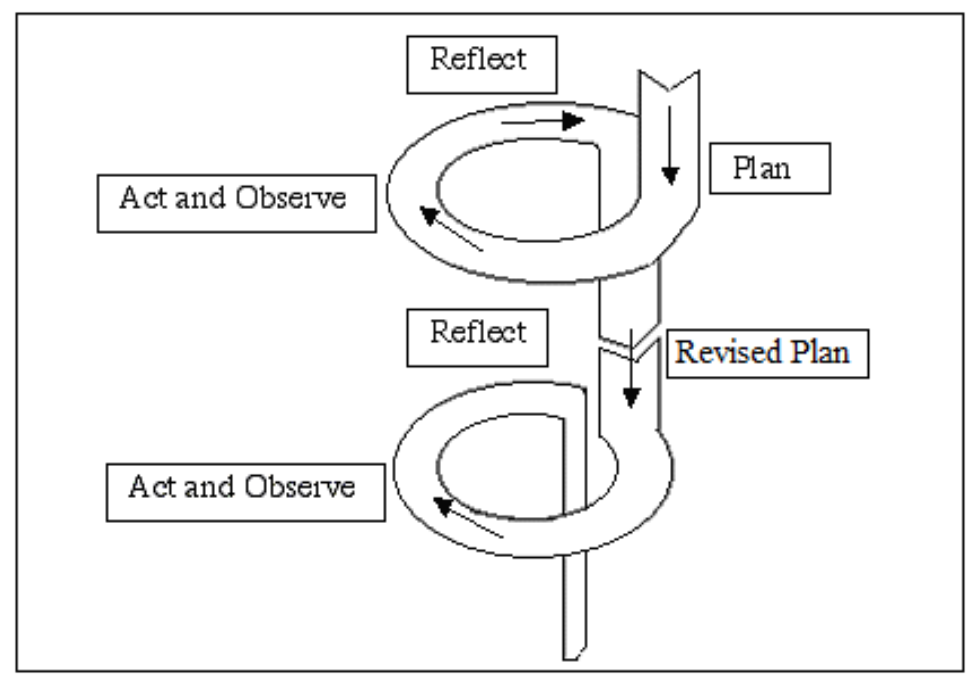

Diagram: Spiral of Action Research (Kemmis \& McTaggart)

\section{FINDINGS AND DISCUSSION}

The purposes of this inquiry were to describe how the process of teaching writing through Clustering Technique in order to improve the students' skill, and the influenced factors of students writing improvement.

To gain the first purpose, the researcher analyzed from the qualitative data which was supported by quantitative data which involved the mean score of students' writing skill in the base score, writing tasks, and post-tests. After analyzing the data, the researcher determined that there was an improvement on the students' writing skill of hortatory exposition through the process brought through Clustering Technique activities. The process covered some activities such as socializing, reviewing, controlling, monitoring, assisting, motivating, and practicing.

Socializing covered the process by explaining the text used, hortatory exposition text, the researcher explained in detail the function, the components, and the language features of hortatory exposition. It was conducted in two meetings of the cycle I. Moreover, he also explained the technique used, Clustering Technique, which involved the function, the steps, and diagram of clustering itself. Socializing was aimed to introduce to the students the technique and the text used in order to obtain a clear understanding.

Reviewing involved the activities in reviewing the previous explanation done by the teacher. In the next meetings either in cycle I and II, the researcher reviewed what he had explained in the previous meeting. The technique used was through asking questions orally. It was proposed to determine how good the students' understanding was.

Controlling and monitoring including the process of observing the students' activities during the teaching and learning process. The controlling and monitoring process was done to find out whether or not the students could do well the activities in class and to determine whether or not the students had problems 


\section{Samsul Amri \\ HORTATORY EXPOSITION TEXT \\ THROUGH CLUSTERING TECHNIQUE}

while writing. The process was done in each meeting during carrying out the research.

Assisting process was done by the researcher to help the students who got difficulties in writing. The students were pleased to ask him while gaining writing problems, which involved in using correct grammar, mechanics, text organization and other problems. Therefore, this process better improves on their writing skill. As the result, the students would be more motivated.

Another important process was practicing. In this case, the students were expected to be able to implement the activities brought through Clustering Technique. They did the process starting from drawing core cluster, drawing other clusters, developing ideas, and starting writing. This process was conducted during carrying the research.

That process was sustained by the quantitative data that showed the increase of the students' writing mean scores from base score (the mean score was 56.32), post-test I (the mean score post-test 1 was 64.23 ), and post-test II (the mean score was 73.85). The improvement involved the indicators of writing skill; grammar, vocabulary, mechanics, fluency, and organization.

The results above were supported by the previous research findings. A research was conducted by Marliasari (2008). Her research findings showed up that the students' participation increased, and it was followed by the improvement of their writing skill. Moreover, Al-Jarf (2009) also carried out a research using Mind Mapping which has the similar concept with Clustering Technique could enhance the freshman students' writing skill. It seems that Mind Mapping is very useful to develop the students' ideas and improve their writing skill. Another research finding was found from Styati (2010) that the students had better writing skill. In other words, the use of Clustering Technique was more effective than direct instruction. Those statements are correct as the result of each cycle that had conducted by the researcher.

In addition, to answer the second research goal, which was related to the factors that influenced the students' improvement on writing skill of hortatory exposition text through Clustering Technique, was based on the results of observations and interviews. After analyzing the data, the researcher found several factors; (1) creative thinking, (2) students' motivation, (3) amount of practice, (4) students' prior knowledge, and (5) teacher's role.

The first factor was creative thinking. The process that brought through Clustering Technique activities encouraged the students to be creative. It could be seen from the beginning of the process that they should draw a core cluster at the center of the paper. In the second step, they had to think a lot of ideas to draw subclusters around the main cluster. They also should relate, select, and develop the ideas in more clusters. At last, they tried to write a hortatory exposition text based on the ideas that they had written on their clustering. Those activities needed high creativity since the students not only think the ideas but also they had to create clustering as well as develop ideas before writing.

To support that finding, according to Murray and Moore (2006:21), in doing writing there is a process which covers starting, progressing and finishing. In addition, Kellogg and Raulerson (2007: 1) add that a good writer is a major cognitive ability because it could be a test of memory, language, and thinking ability. Those theories proved that in writing needed cognitive ability, which 
includes creative thinking since while doing writing there is a process in ideas to write. Moreover, to sustain the finding above, the researcher presented several other research findings that prove students' creativity affected on their writing proficiency. Rofiuddin (2003) states that creativity has effects on students' reading and writing skills. In line with this point, Azis (2009) added that there was a relationship between attitude creative and creative writing skill. It could be concluded that those theories and findings supported enough this research finding that creative thinking was one of the factors that influenced the improvement of the students' writing skill of hortatory exposition text.

The second factor was the students' motivation. No doubt that motivation has an essential role in teaching and learning process. In this research, motivation was considered as one factor that influenced the students' writing skill improvement. It could be found from their attitudes during teaching and learning process. The students mostly could give positive response while being asked by the teacher, and they were also enthusiastic and interested in giving opinions or ideas about the topic given. It seemed that they were motivated through the activities brought by the teacher. It could positively affect the students' writing skill of hortatory exposition text due to having high motivation. Moreover, according to the results of field notes in the second meeting of cycle II, it could be found that the teacher encouraged the students to do the best one in their writing. It was expected to motivate them in order to have better improvement on their writing skill of hortatory exposition text.

To support the finding, the researcher presented some theories that related to the finding. Tamimi and Shuib (2009) viewed that the importance of motivation in enhancing second or foreign language learning is undeniable. In other points of view, Gupta and Woldemariam (2011:35) stated that students with strong motivation demonstrated a high level of enjoyment, confidence, perceived ability, and positive attitude towards effective teaching methods of writing, and they were found to have employed writing strategies most frequently. To sum up, motivation had the essential role in the learning process, especially for writing skill. The students who had high motivation could achieve high results in their writing skill.

The third factor was the number of writing practices. The researcher could find that the students could improve their writing skill after doing a lot of writing class. It meant that the number of writing practices had a big effect on their writing improvement. It was relevant with the theories proposed by Nation (2009:93-94) that different genre uses different writing conventions and draw on different language features, so it is useful to make sure that learners are getting writing practice in the range of genres that they will have to write in. Gupta and Woldemariam (2011:35), Cavkaytar and Yasar (2008:6) argued that students who frequently practiced writing could achieve expected grades or to become competitive in writing. Thus, enough time should be given to students to internalize the writing process.

Another factor that influenced the students' writing skill improvement was students' prior knowledge. Nation (2009:94) supported that finding, which learners should experience a feeling of success in most of their writing, and a teacher could think of a topic that learners are very familiar with. Similarly, learners should bring experience and knowledge to their writing. 
Teacher's role was another factor which influenced the students' writing skill improvement. In this case, the teacher always tried to do his best in the classroom. He controlled the students while doing writing as well as assisting them. Since the teacher had a good approach to the students, they were not afraid to ask him while getting problems with their writings. It made the atmosphere was more comfortable. Those findings were supported by Trigwell, et.al (1999:66) clarify that good teaching is defined as teaching that involves giving helpful feedback, making an effort to understand the students' difficulties, being good at explanation, making subject interesting, getting the best outcomes of the students, motivating the students, and showing interest in what the students have. In line this point, Ilyana, et.al (2008:1) found in their research that the changes of learners' writing skills were based on the learners' compositions and related to the teacher's assistance given. In other words, the teacher's assistance affected the production of the students' composition. Clearly, the theories above supported the finding of this research that teacher's role was one of the factors of students' writing improvement.

To sum up, the analysis above had answered two research questions that the application of Clustering Technique was able to provide valuable contributions by improving the students' writing skill of hortatory exposition text. Moreover, it was also found some factors that influenced the students' writing skill improvement.

\section{CONCLUSION}

After analyzing the data, it could be concluded that the students' writing skill improves through the process of Clustering Technique activities which were implemented in teaching and learning process. The process involves socializing, reviewing, controlling, monitoring, assisting, motivating, and practicing. Furthermore, there were five factors that influenced the improvement of the students' writing skill of hortatory exposition text through Clustering Technique; creative thinking, students' motivation, amount of practice, students' prior knowledge, and teacher's role.

Referring to the research findings, the researcher implies for the next teaching and learning process that Clustering Technique could be chosen as a technique to solve students' learning problems which are related to improving the students' writing skill. The research findings of this research can be considered by the English teacher since it has been proved that through Clustering Technique, the students' writing skill could improve. Furthermore, there was a possibility to apply Clustering Technique for other texts, since it could help the students to generate ideas as many as possible before writing.

\section{REFERENCES}

Al-Jarf, Reima. (2009). "Enhancing Freshman Students' Writing Skills with A Mind Mapping Software". The $5^{\text {th }}$ International Scientific Conference, ELearning and Software for Education. Bucharest. Retrieved on September $15^{\text {th }}, 2015$ 
Anna, Uhl Chamot, et.al. (2006). Conducting Action Research in the Foreign Language Classroom. Washington, DC: National Capital Language Resource Center. Retrieved on December 20 ${ }^{\text {th }}, 2015$

Azis, Rahmat. (2009). "Karakteristik Pribadi Kreatif dan Kemampuan Menulis Kreatif”. Anima, Indonesian Psychological Journal. Vol. 24. No.2, 116123.

Brown, H. Doughlas. (2001). Teaching by Principle: An Imperative Approach to Language Pedagogy $\left(2^{\text {nd }} e d\right)$. New York: Addison Wesley Longman, Inc.

Cavkaytar, Serap and Sefik Yasar. (2008). "Using Writing Process in Teaching Composition Skills: An Action Research". International Conference "ICT for Language Learning" $3^{\text {rd }}$ edition.

Creswell, John W. (2005). Educational Research (2 ${ }^{\text {nd }}$ ed). New Jersey: Pearson Prentice Hall.

Dawson, Melanie and Joe Essid. (2015). Prewriting: Clustering. Retrieved on April 15 ${ }^{\text {th }}, 2015$, http://writing2.richmond.edu/writing/wweb/cluster.html.

Derewianka, Beverly. (1992). Exploring How Texts Work. Canberra: Primary English Teaching Association.

Grace, Eudia and Sudarwati, Th.M. (2006). Look Ahead An English Course for Senior High School Students Year XI Science and Social Study Program. Jakarta: Erlangga.

Gupta, Deepti and Gethachew S. Woldemariam. (2011). The Influence of Motivation and Attitude on Writing Strategy Use of Undergraduate EFL Students: Qualitative and Quantitative Perspectives. The Asian EFL Journal Quarterly June 2011, Vol. 13. Issue 2.

Hartono, Rudi. (2005). Genres of Texts. Semarang: English Dept. Faculty of Language and Arts. Semarang State University

Heaton, J.B. (1991). Writing English Language Test. New York: Longman, Inc.

Homstad, Torild and Herga Thorson. (1994). "Writing Theory and Practice in the Second Language Classroom: A Selected Annotated Bibliography." Technical Report Series No. 8. The Board of Regents, University of Minnesota.

Hughes, Arthur. (2003). Testing for Language Teachers $\left(2^{\text {nd }}\right.$ ed). New York: Cambridge University Press

Ilyana, et. al. (2008). The Effect of Teacher's Assistance on Rural Learners' Writing Skills and Self-Efficacy: A Case Study. Seminar Penyelidikan Siswazah. Universitas Kebangsaan Malaysia. 
Kellogg, R,T \& Bascom. A.R. (2007). Improving the Writing Skills of College Students. Psychonomic Bulletin \& Review No. 14 (2), 237-242. Saint Louis University

Kemmis, S. \& McTaggart, R. (1988). The Action Research Planner. Melbourne: Deakin University Press.

Li, Daqi. (2000). "Effect of Story Mapping and Story Map Questions on the Story Writing Performance of Students with Learning Disabilities." Unpublished Dissertation. Texas: Texas Tech University

Lindbergh, Anne.M. (2008). Prewriting Strategies Getting Started. Companion Website. Retrieved on June $1^{\text {st }}, 2015$, http://academic.cengage.com/ english/Connelly/SundanceWriter4e

Marliasari, Devi. (2008). "Using Clustering Technique to Improve the Senior High School Students' Abilities in Generating Ideas for Writing Analytical Exposition." Unpublished Thesis. Malang: State University of Malang.

Mumtaz. (2007). The Use of Written Feedback and Conferencing in Improving Students' Writing. Johor: Technology University of Malaysia. Retrieved on $2^{\text {nd }}, 2015$

Murray, Rowena \& Sarah Moore. (2006). The Handbook of Academic Writing: A Fresh Approach. New York: Open University Press.

Myles, Johanne. (2002). Second Language Writing and Research: The Writing Process and Error Analysis in Student Texts. TESL-English Journal, vol.6, N.2. A-1.2002.

Nation, I.S.P. (2009). Teaching ESL/EFL Reading and Writing. New York: Routledge

O'Malley, J. M and Pierce, L.V. (1995). Authentic Assessment for English Language Learners, Practical Approaches for Teachers. New York: Addition-Wesley Publishing Company.

Oshima, Alice and Hogue. (1999). Writing Academic English. New York: Addson Wesley Longman.

Partel, M.F and Praveen. M. Jain . (2008). English Language Teaching (Methods, Tools \& Techniques). Jaipur: Sunrise Publishers and Distributions.

Richard, J.C and Willy A.R (Eds). (2010). Methodology in Language Teaching. An Anthology of Current Practice. New York: Cambridge University Press.

Rofiuddin, Ahmad. (2003). Faktor Kreativitas dalam Kemampuan Membaca dan Menulis Siswa Sekolah Dasar. Bahasa dan Seni Journal. Th. 31. No.2. 
WEJ, Vol 2 No 2 September 2018

Styati, Erlik Widiyani. (2010). "The Effectiveness of Clustering Technique to Teach Writing Skill Viewed from Students' Linguistics Intelligence (An Experimental Research on Descriptive Writing for the Second Semester of English Department of IKIP PGRI Madiun in the Academic Year of 2009/2010." Unpublished Thesis. Solo: Sebelas Maret University.

Tamimi, Atef and Munir Shuib. (2009). Motivation and Attitudes towards Learning English: A Study of Petroleum Engineering Undergraduates At Hadhramout University Of Sciences And Technology. GEMA Online Journal of Language Studies. Vol. 9 (2). 